\title{
PENERAPAN AKAD MURABAHAH DALAM PRODUK PEMBIAYAAN BAGI PENSIUNAN DI BSM KCP BONDOWOSO
}

\author{
Aminuddin \& Tholhah \\ Email: drsaminuddin1968@gmail.com
}

\begin{abstract}
This study examines the application of murabahah contracts on pension financing products conducted at Bank Syariah Mandiri KCP Bondowoso between the bank and its customers based on DSN-MUI fatwa Number 4 of 2000 concerning murabahah financing and DSN-MUI fatwa Number 88 of 2013 concerning General Guidelines for Program Implementation Pension Based on Sharia Principles. The problems that will be answered through this research are: (1) How is the application of the murabahah contract to pension financing products in Bank Syariah Mandiri KCP Bondowoso? (2) What is the DSN-MUI fatwa review of the application of the murabahah contract to pension financing products at Bank Syariah Mandiri KCP Bondowoso? This research is field research, because research activities are conducted at Bank Syariah Mandiri KCP Bondowoso. The research approach used is a qualitative descriptive research approach. To understand and analyze the object under study, the author uses several approaches such as the legislative approach and the comparative approach. Data collection techniques using observation, documentation, and interview techniques. While the data analysis technique uses a comparative analysis method.

The results of this study are: (1) The pension financing contract in Bank Syariah Mandiri KCP Bondowoso is carried out by using a murabahah contract by fulfilling the following conditions: (1) The contract is done by reciting ijab and qabul; (2) Contracts are clearly implemented; (3) The object of the contract has been fully owned by the bank before being offered to prospective customers; (4) Contracts are carried out by prospective customers and the bank voluntarily without any coercion or threat; and (5) Contract objects are goods that are not prohibited by sharia. In the event of default, the bank will carry out billing steps by sending a notification letter, collection letter, warning letter 1 to 3. If the customer becomes bankrupt, the Bank will give up the time when it is able to settle its obligations if the business is bankrupt in an agreement the bank with the customer at the time of the murabahah agreement. (2) In general, the application of murabahah contracts to pension financing products at Bank Syariah Mandiri KCP Bondowoso is in accordance with the DSN-MUI fatwa, both DSN-MUI fatwa Number 4 of 2000 concerning Financing of Murabahah, and DSN-MUI fatwa Number 88 of 2013 concerning Guidelines General Implementation of Sharia Principles Based Pension Programs.
\end{abstract}

Keywords: Fatwa, DSN-MUI, Murabahah, Pension, Bank Syariah Mandiri.

\section{PENDAHULUAN}

Perbankan syariah merupakan salah satu doktrin ekonomi Islam sebagai bentuk dari hasil ijtihad terhadap sumber-sumber hukum naqli. Salah satu ciri yang membedakan antara perbankan syariah dengan perbankan konvensional adalah terbebasnya praktek riba dalam 
operasionalnya. Karena itu bank syariah dalam penerapannya sangat memperhatikan kinerja dan ketahanan bank dengan tanpa menggunakan hasil bunga sebagai sumber pokok untuk membiayai operasional bank.

Perbankan tanpa bunga sebagai lembaga intermediasi mulai diakui dalam Undang-Undang Nomor 7 Tahun 1992 tentang Perbankan (LN 1992 No. 31 dan sebagai aturan pelaksanaan Undang-Undang Nomor 7 Tahun 1992 dikeluarkan Peraturan Pemerintah No. 72 Tahun 1992 tentang Perbankan berdasarkan prinsip bagi hasil). Dengan adanya perubahan atas UndangUndang Nomor 7 Tahun 1992 tentang perbankan dengan Undang-Undang Nomor 10 Tahun 1998 tentang perubahan atas Undang-Undang Nomor 7 Tahun 1992 tentang perbankan (LN 1998 No. 182) dan diundangkannya Undang-Undang Nomor 21 Tahun 2008 tentang Perbankan Syariah, maka telah ada landasan hukum yang lebih jelas dan lebih luas dalam pengembangan bank tanpa bunga yang kemudian dikenal dengan istilah bank berdasarkan prinsip syariah. ${ }^{1}$

Meskipun demikian harus diakui bahwa bank yang beroperasi berdasarkan pada prinsip syariah, dimulai dengan didirikannya Bank Muamalat Indonesia pada tahun 1991, dan kemudian disusul dengan berdirinya BPR berdasarkan prinsip yang sama yang mana terlibat dalam pengembangan bisnis-bisnis syariah, memiliki motivasi yang berbeda-beda. Artinya motivasi para usahawan tersebut dalam menggeluti bisnis berbasis syariah tidak lagi murni motivasi agama, tetapi lebih pada mengedepankan aspek ekonomi semata. Karena itu wajar apabila pada saat ini banyak bank umum (konvensional) yang membuka salah satu cabangnya sebagai bank syariah guna menjalankan bisnis yang dikenal oleh masyarakat luas sebagai bisnis syariah.

Perkembangan bank syariah di Indonesia tidak terlepas dari situasi politik yang melingkupi kehadirannya dan masalah yuridis berkaitan dengan persentuhan antara hukum syariah dengan hukum nasional dan hukum Barat. Hal ini menuntut bank syariah untuk menyesuaikan diri dengan hal tersebut. Pendirian bank-bank berbasis syariah di Indonesia dipengaruhi oleh pemikiran dan upaya para ulama serta para ahli ekonomi Islam serta perkembangan dan kemajuan perbankan syariah di negara-negara lain. Namun demikian pengembangan bank syariah di Indonesia relatif lambat jika dibandingkan dengan negara-negara lainnya. Hal ini sebagai akibat dari kendala dasar hukum, pertimbangan sosial politik, serta perbedaan pandangan para ulama Indonesia tentang bunga bank. Selain itu perkembangan bank syariah di Indonesia

\footnotetext{
${ }^{1}$ Abd. Shomad, Hukum Islam: Penormaan Prinsip Syariah Dalam Hukum Indonesia, (Jakarta: Kencana, 2010),
} 113. 
juga tidak terlepas dari perkembangan hukum Islam yang di antaranya dapat ditelusuri dari perkembangan Peradilan Agama. Hal ini bukan semata-mata karena perkara bank syariah menjadi kewenangan Pengadilan Agama, namun juka karena fluktuasi penerapan syariah dalam berbagai aspek hukumnya dapat juga ditelaah melalui fluktuasi kewenangan Pengadilan Agama. ${ }^{2}$

Bank syariah memiliki peranan penting dalam menjalankan sistem keuangan nasional di Indonesia saat ini. Setidaknya peranan tersebut dapat dilihat pada beberapa hal berikut: (1) Pengalihan aset (Asset Transmutation). Sebagaimana diketahui bahwa sumber dana yang diberikan oleh bank syariah berasal dari pemilik dana sebagai unit surplus. Adapun jangka waktunya dapat diatur sesuai dengan kehendak pemilik dana sehingga bank syariah dalam hal ini berperan sebagai pengalih aset dari unit surplus kepada unit defisit atau kepada pihak-pihak yang membutuhkan pembiayaan baik dalam bentuk akad jual beli, sewa-menyewa, atau dengan akad lainnya; (2) Transaksi (Transaction). Bank syariah dalam peranan ini memberikan layanan dan kemudahan kepada pelaku ekonomi guna melaksanakan berbagai transaksi keuangan berkaitan dengan barang maupun jasa; (3) Liquiditas (Liquidity). Bank syariah memiliki peran sebagai penjaga liquiditas masyarakat dengan adanya aliran dana dari unit surplus kepada unit defisit yang dijalankan melalui mekanisme pengelolaan penghimpunan serta penyaluran dana dari dan kepada masyarakat; dan (4) Broker for Business. Bank syariah dapat pula berperan sebagai broker dimana bank dapat mempertemukan para pebisnis untuk mewujudkan efisiensi biaya ekonomi dalam berbagai macam bisnis yang dijalankan seperti jual beli, sewa-menyewa, serta berbagai macam kerjasama bagi hasil. ${ }^{3}$

Dalam menjalankan fungsinya, bank syariah diwajibkan menggunakan prinsip-prinsip yang sesuai dengan sistem, nilai dan etos Islam. Setidaknya dalam hal ini ada lima prinsip yang disepakati oleh para ulama untuk menjalankan aktivitas ekonomi Islam, yaitu prinsip tauhid (monotheisme), khilafah, 'adalah (keadilan), ta'awun (tolong-menolong), dan maslahah (kemaslahatan). Adapun di antara prinsip perbankan syariah yang paling menonjol adalah pada sistem profit-lost sharing. Sistem ini didasarkan kepada kaidah yang terjadi dalam fiqh muamalah yaitu al-Ghunmu bi al-Ghanmi (No return without risk/keuntungan karena adanya tanggung jawab resiko). Hal ini menunjukkan bahwa keuntungan tidak boleh dituntut tanpa ada kemungkinan menanggung resiko. Implikasi dari prinsip ini mendukung berbagai kegiatan

\footnotetext{
${ }^{2}$ Ibid, 114.

${ }^{3}$ Abd. Hadi, Memahami Akad-Akad Dalam Perbankan Syariah Serta Dasar Hukumnya, (Surabaya: Sinar Terang, 2015), 125-126.
} 
investasi dan ekonomi yang akan memberikan dampak positif pada ekonomi riil berdasarkan keadilan sebagai investor dan pengelola. ${ }^{4}$

Di antara bank-bank berbasis syariah yang juga menjalankan fungsi dan prinsip-prinsip syariah sebagaimana disebutkan di atas adalah Bank Syariah Mandiri. Adapun Bank Syariah Mandiri merupakan anak perusahaan dari PT. Bank Mandiri Persero Tbk. Bank Syariah Mandiri merupakan salah satu Bank Syariah yang berkembang pesat di hamper seluruh wilayah negara Indonesia. Untuk memenuhi kebutuhan masyarakat di Indonesia, Bank Syariah Mandiri membuka kantor cabang di setiap wilayah, terutama di kota-kota tingkat kabupaten. Pada prinsipnya Bank Syariah melakukan penghimpunan dana dan menyalurkannya dalam bentuk pembiayaan. Dalam penghimpunan dana tersebut Bank Syariah Mandiri mempunyai produkproduk yang ditawarkan kepada masyarakat seperti produk tabungan, giro dan deposito, yang menggunakan akan mudharabah dan wadiah. Adapun untuk penyaluran dana, kebanyakan Bank Syariah Mandiri menggunakan pembiayaan dalam akad murabahah (jual beli) dan ijarah (sewa menyewa), musyarakah (perseroan), dan mudharabah (bisnis bagi hasil).

Di antara cabang dari Bank Syariah Mandiri adalah Bank Syariah Mandiri KCP Bondowoso. Bank Syariah Mandiri KCP Bondowoso didirikan pada tanggan 28 desember 2010 dengan alamat J1. PB Sudirman no. 1 Bondowoso. Sebagaimana bank-bank berbasis syariah lainnya, Bank Syariah Mandiri KCP Bondowoso memiliki produk-produk yang ditawarkan kepada masyarakat seperti produk simpanan (tabungan, deposito, dan giro) dan produk pembiayaan (musyarakah, mudharabah, murabahah, pembiayaan pensiun, griya BSM bersubsidi, kendaraan bermotor, dan sebagainya).

Produk Bank Syariah Mandiri KCP Bondowoso yang cukup diminati oleh masyarakat adalah produk-produk pembiayaan di antaranya adalah pembiayaan pensiun. Karena produk ini selain dibutuhkan oleh banyak masyarakat yang memasuki masa pensiun, juga dirasa sangat membantu memecahkan kesulitan finansial mereka manakala ada kebutuhan yang mendesak. Kebutuhan untuk menghimpun dan menyalurkan dana pensiun ini dipandang sebagai potensi yang mulai ditangkap oleh beberapa bank syariah di Indonesia, salah satunya adalah Bank Syariah Mandiri. Bank Syariah Mandiri saat ini sudah memiliki produk pembiayaan pensiun. Pengertian dari pembiayaan pensiun itu sendiri adalah penyaluran fasilitas pembiayaan kepada nasabah dimana pembiayaan ini juga termasuk pembiayaan multiguna kepada para pensiunan

\footnotetext{
${ }^{4}$ Cholil Nafis, Teori Hukum Ekonomi Syariah. (Jakarta: UI Press, 2011), 139-140.
} 
dan pembayaran dilakukan dengan cara angsuran pada setiap bulannya melalui pemotongan uang pensiun.

Akad yang digunakan oleh Bank Syariah Mandiri KCP Bondowoso adalah akad murabahah. Karena akad murabahah terbukti lebih menguntungkan terutama bagi pihak bank. Di antara keuntungan yang dimaksud adalah adanya selisih dari harga beli dari penjual dengan harga jual kepada nasabah. Selain itu proses administrasinya pun tidak rumit dan lebih memudahkan bagi nasabah yang membutuhkan dana dalam waktu yang relatif singkat. Keuntungan produk pembiayaan melalui akad murabahah ini pun dapat dirasakan oleh nasabah yang memiliki finansial terbatas namun dapat memenuhi kebutuhan yang diinginkan, dengan pembayaran angsuran yang meringankan baginya. Karena itu dapat dikatakan bahwa manfaat dari pembiayaan pensiun antara lain dapat memberikan kesempatan dan kemudahan bagi masyarakat usia pension dalam memperoleh pembiayaan, meningkatkan kualitas hidup mereka, pembayaran angsuran dengan memotong langsung dana pensiunan setiap bulan yang dikelola oleh BSM yang dalam hal ini adalah Bank Syariah Mandiri KCP Bondowoso.

Namun demikian sangat penting untuk memperhatikan terpenuhinya syarat dan rukun akad demi mewujudkan keabsahan akad utang-piutang di atas secara hukum. Karena dampak yang ditimbulkan oleh akad yang sah sangat berpengaruh kepada timbulnya hak dan kewajiban masing-masing pihak yang berakad, seperti peralihan hak, timbulnya tanggung jawab, hingga timbulnya kewajiban. Lebih-lebih berkaitan dengan akad maliyah seperti jual beli, sewamenyewa, utang-piutang dan sebagainya, dimana akad-akad semacam itu dapat menimbulkan perpindahan hak milik atau menimbulkan kewajiban timbal balik antara para pihak yang melakukan akad.

Di sisi lain, menurut beberapa hasil penelitian sebelumnya tentang penerapan akad murabahah di lembaga-lembaga keuangan syariah, rata-rata peneliti menyimpulkan bahwa penerapannya masih belum sesuai dengan hukum syariah, baik berkaitan dengan akad yang dilakukan, maupun proses pelaksanaannya. Hal inilah yang menarik minat penulis untuk ingin mengetahui lebih jauh tentang bahaimana konsep murabahah diterapkan dalam sistem perbankan syariah saat ini. Mengingat pentingnya permasalahan tentang penerapan akad murabahah yang harus sesuai syariah ini, maka tujuan yang ingin dicapai dalam penelitian ini adalah untuk mengetahui secara mendalam penerapan akad murabahah, apakah transaksi yang dilakukan antara nasabah dan Bank Syariah Mandiri KCP Bondowoso berkaitan dengan pembiayaan 
pensiun yang diberikan oleh Bank Syariah Mandiri KCP Bondowoso kepada nasabahnya telah sesuai dengan fatwa DSN-MUI tentang pembiayaan murabahah.

Berkaitan dengan judul yang penulis pilih tersebut, maka setidaknya ada dua permasalahan yang akan dijawab melalui penelitian ini, yaitu: (1) Bagaimana penerapan akad murabahah pada produk pembiayaan pensiun di Bank Syariah Mandiri KCP Bondowoso? (2) Bagaimana tinjauan fatwa DSN-MUI terhadap penerapan akad murabahah pada produk pembiayaan pensiun di Bank Syariah Mandiri KCP Bondowoso?

\section{METODE PENELITIAN}

Dilihat dari jenisnya, penelitian ini adalah penelitian lapangan (field research), karena kegiatan penelitian dilakukan di Bank Syariah Mandiri KCP Bondowoso.. Adapun pendekatan penelitian yang digunakan adalah pendekatan penelitian deskriptif kualitatif. Yaitu suatu pendekatan dalam penelitian yang digunakan untuk memahami fenomena tentang apa yang di alami oleh subjek dan objek penelitian. ${ }^{5}$ Untuk memahami dan menganalisis objek yang diteliti, penulis menggunakan beberapa pendekatan lainnya sebagai berikut: (1) Pendekatan perundangundang, karena sebagaimana dijelaskan bahwa penelitian ini tidak dapat terlepas dari penggunaan dan analisis tentang sumber-sumber penelitian dari undang-undang, seperti UndangUndang Perbankan Syariah, dan sebagainya. Artinya, dengan menggunakan pendekatan perundang-undangan, objek penelitian ini, yakni penerapan akad murabahah pada pembiayaan pensiun di Bank Syariah Mandiri KCP Bondowoso. ini akan dianalisis secara mendalam dan komprehensif berdasarkan hukum ekonomi syariah myang bersumber dari fatwa-fatwa DSNMUI yang mengaturnya. Sehingga hasil penelitian ini diharapkan dapat memberikan informasi yuridis kepada semua pihak mengenai tujuan atau maksud dalam penelitian ini. (2) Pendekatan perbandingan, pendekatan ini digunakan untuk melakukan analisis perbandingan guna menemukan kesesuaian dan ketidaksesuaian antara implementasi atau penerapan akad murabahah di lokasi penelitian dengan putusan fatwa DSN-MUI yang menentukan secara tegas tata aturan penerapan akad dengan model murabahah. Melalui pendekatan perbandingan ini akan dapat diketahui sejauh mana Bank Syariah Mandiri KCP Bondowoso. mematuhi fatwa DSN-MUI terkait dengan penerapan akad pembiayaan pensiun yang dilaksanakan.

\footnotetext{
${ }^{5}$ Lexi J. Moleong, Metodologi Penelitian Kualitatif, (Bandung: Rosda Karya, 2007), 6 dan 11.
} 
Dalam penelitian ini sumber data primer yang akan digunakan diantaranya: (1) UndangUndang Republik Indonesia Nomor 21 Tahun 2008 Tentang Perbankan Syariah. (2) Fatwa DSN-MUI Nomor 4 Tahun 2000 tentang Akad Murabahah. (3) Fatwa DSN-MUI Nomor 88 Tahun 2013 tentang Pedoman Umum Penyelenggaraan Program Pensiun Berdasarkan Prinsip Syariah. (4) Kompilasi Hukum Ekonomi Syariah.

Teknik pengumpulan data dengan menggunakan teknik observasi, dokumentasi, dan wawancara. Sedangkan teknik analisis data menggunakan metode analisis perbandingan.

\section{PEMBAHASAN}

\section{Mekanisme Pembiayaan Pensiun di Bank Syariah Mandiri KCP Bondowoso}

Menurut pimpinan Bank Syariah Mandiri KCP Bondowoso, Dheny Yulianto, pembiayaan kepada konsumen atau nasabah merupakan salah satu segmen yang memiliki kontribusi sangat besar terhadap pengembangan pertumbuhan bisnis Bank Syariah Mandiri KCP Bondowoso. Karena itu perusahaan menyediakan berbagai macam produk pembiayaan yang disesuaikan dengan nimat dan kebutuhan masyarakat terutama di Bondowoso. Adapun salah satu produk yang paling diminati adalah priduk pembiayaan pensiun. Produk pembiayaan pensiunan ini menurut pengakuannya hanya ditujukan kepada para pensiunan Pegawai Negeri Sipil Pusat dan Daerah, TNI, POLRI, serta para pensiunan pegawai BUMN/Swasta/Asing. ${ }^{6}$

Selama ini menurut Dheny, Produk pembiayaan pensiunan tersebut merupakan salah satu produk yang sangat diminati oleh masyarakat setempat, khususnya bagi para pensiunan pegawai pemerintah daerah Kabupaten Bondowoso. Produk tersebut dirasa dapat membantu memenuhi kebutuhan para masyarakat pada usia pensiun, sehingga banyak dari mereka yang menjadi konsumen produk pensiun ini. Di samping itu banyak para pensiunan yang memutuskan untuk mengambil produk pembiayaan pensiun di Bank Syariah Mandiri KCP Bondowoso ini, karena jika dilihat dari segi margin yang ditetapkan di Bank Syariah Mandiri KCPP Bondowoso tersebut dapat dikatakan memiliki margin yang paling rendah apabila dibandingkan dengan margin pada bank-bank lain yang ada di Bondowoso, baik bank syariah maupun bank konvensional.

\footnotetext{
${ }^{6}$ Hasil wawancara dengan pimpinan Bank Syariah Mandiri KCP Bondowoso, Dheny Yulianto, pada tanggal 26 Januari 2019.
} 
Berkaitan dengan limit pembiayaan pensiun tersebut, Dheny menjelaskan bahwa para pensiunan dapat mengajukan pembiayaan mulai dari jumlah minimal yaitu Rp. 10.000.000 hingga jumlah maksimal yaitu Rp. 300.000.000 dalam jangka waktu angsuran maksimal selama 15 tahun. Adapun mengenai mekanisme atau prosedur pengajuan pembiayaan pensiun di Bank Syariah Mandiri KCP Bondowoso, menurut Dheny dilakukan dengan tahapan-tahapan berikut ini: ${ }^{7}$

(1) Nasabah datang ke kantor Bank Syariah Mandiri KCP Bondowoso untuk mengajukan permohonan pembiayaan pensiunan dengan mengisi formulir permohonan pembiayaan dilengkapi dengan dokumen berupa fotocopy KTP, fotocopy KK, fotocopy surat nikah, fotocopy karip, fotocopy SK pensiun, mutasi rekening, fotocopy NPWP, dan juga pasfoto berwarna beberapa buah.

(2) Bagian marketing pensiun (Consumer Banking Relationship Manager/CBRM) akan melakukan verifikasi dokumen atas permohonan pembiayaan yang diajukan nasabah dengan melakukan pengecekan secara detail atas dokumen-dokumen yang telah diserahkan termasuk verifikasi apakah pembiayaan akan take over dari bank lain atau tidak.

(3) Setelah dilakukan verifikasi kelengkapan dokumen, kemudian akan dilakukan peng-input-an dokumen-dokumen tersebut ke sistem komputer untuk dihitung berapa plafond pembiayaan yang bisa diberikan.

(4) Hasil inputan sistem tersebut kemudian akan dimintakan review di bagian analis pembiayaan pensiun.

(5) Ketika hasil analisa sudah selesai dilakukan, selanjutnya akan dimintakan persetujuan ke pejabat pemutus pembiayaan pensiun (kemungkinan plafond bisa sama dengan pengajuan atau lebih rendah dari pengajuan).

(6) Setelah diputus oleh pejabat yang berwenang maka diterbitkan SP3 (Surat Pemberitahuan Persetujuan Pembiayaan) untuk diberikan kepada nasabah.

(7) Jika nasabah setuju maka dibuatkan akad pembiayaan lengkap (jenis barang, harga, biaya pengadaan barang, jangka waktu pembayaran, jumlah angsuran, serta mekanisme pelunasan).

(8) Dilakukan akad yang dihadiri oleh nasabah, pejabat bank serta marketing.

\footnotetext{
${ }^{7}$ Hasil wawancara dengan pimpinan Bank Syariah Mandiri KCP Bondowoso, Dheny Yulianto, pada tanggal 26 Januari 2019.
} 
(9) Setelah akad selesai dilaksanakan maka dokumen segera dikirim ke bagian pencairan pembiayaan.

(10) Hasil pencairan langsung masuk ke rekening nasabah untuk kemudian dilakukan pembayaran atas barang yang akan dibeli.

Proses tersebut dapat dilakukan dengan catatan bahwa calon nasabah memiliki beberapa kriterian sebagai berikut: (1) Cakap Hukum; (2) Calon nasabah yang melakukan pengajuan pembiayaan pensiun adalah pensiunan Pegawai Negeri Sipil Pusat/Daerah, TNI, POLRI, Pensiunan Pegawai BUMN/Swasta/Asing yang memperoleh penghasilan pensiun secara rutin (pensiun bulanan); (3) Pada saat jatuh tempo pembiayaan, usia nasabah maksimal adalah 70 tahun; dan (4) Calon nasabah bersedia memindahkan pembayaran pensiun bulanannya melalui Bank Syariah Mandiri.

\section{Penerapan Akad Murabahah Pada Pembiayaan Pensiun}

Berdasarkan hasil wawancara yang penulis lakukan dengan pimpinan Bank, ${ }^{8}$ ada beberapa poin yang perlu diperhatikan pada pelaksanaan pembiayaan pensiun dengan akad murabahah Bank Syariah Mandiri KCP Bondowoso, yaitu:

(1) Akad dilakukan dengan mengucapkan ijab dan qabul. Akad pembiayaan pensiun di Bank Syariah Mandiri KCP Bondowoso dilakukan dengan mengucapkan ijab dan qabul dengan menerangkan bahwa akad tersebut dimaksudkan untuk pembiayaan pensiun yang disalurkan. Akad yang dilakukan menggunakan akad murabahah dengan obyek murabahah tergantung pada pembiayaan yang diajukan nasabah (bisa kendaraan, tanah, barang dagangan dan lainlain obyek jual beli yang tentunya sesuai dengan syariah).

(2) Akad dilaksanakan secara jelas. Adapun kejelasan yang dimaksud berkaitan dengan jenis barang, harga, biaya pengadaan barang, jangka waktu pembayaran/pelunasan. Menurut pihak bank, dalam akad dilaksanakan secara jelas dengan menjelaskan secara terperinci tentang jenis jenis barang yang diakadkan, harga jual yang ditentukan, biaya pengadaan barang, serta jangka waktu pembiayaan berapa lama, termasuk juga ketentuan yang boleh ditempuh jika pembayaran akan dilunasi sebelum waktunya. Apabila nasabah setuju maka dibuatkan akad pembiayaan lengkap (jenis barang, harga, biaya pegadaan barang jangka

\footnotetext{
${ }^{8}$ Hasil wawancara dengan pimpinan Bank Syariah Mandiri KCP Bondowoso, Dheny Yulianto, pada tanggal 26 Januari 2019.
} 
waktu pembayaran, jumlah angsuran dan mekanisme pelunasannya. Terkait dengan ketentuan pembayaran angsuran, nasabah dapat mulai membayar angsurannya setelah melakukan penandatangan akad, dan untuk jumlah besaran angsuran yang akan dibayar oleh nasabah secara rutin setiapbulannya telah di tentukan di awal akad dan tidak akan terjadi perubahan hingga waktu berakhirnya pembayaran angsuran pembiayaan pensiun tersebut.

(3) Objek akad telah sepenuhnya menjadi milik bank sebelum ditawarkan ke calon nasabah. Ketika penulis mengajukan pertanyaan tentang apakah barang yang diakadkan dengan murabahan telah sepenuhnya menjadi milik pihak bank sebelum akad dengan nasabah terjadi? Maka jawaban yang penulis peroleh dari pihak bank adalah bahwa karena prinsip murabahah adalah jual beli maka benar kepemilikan barang sepenuhnya telah dikuasai oleh bank. Menurut pihak bank, dalam beberapa case maka akan ditambahkan akad wakalah dimana bank mewakilkan kepada nasabah untuk melakukan pembelian barang sesuai yang diinginkan.

(4) Akad dilakukan oleh calon nasabah dan pihak bank dengan suka rela tanpa ada paksaan atau ancaman. Pada pembiayaan pensiun di Bank Syariah Mandiri KCP Bondowoso, setelah pihak bank menyetujui pengajuan pembiayaan tersebut, maka aka nada utusan dari bank yang datang kepada nasabah untuk melakukan penandatanganan akad yang mana dalam proses tersebut tidak ada unsur paksaan atau ancaman apapun. Artinya antara pihak nasabah dan pihak bank telah sama-sama rela untuk melakukan akad. Dalam proses akad tersebut juga dihadirkan seorang notaries, hal tersebut untuk membuktikan bahwa dalam proses akad tersebut tidak ada unsur paksaan sama sekali. Kerelaan antara pihak yang berakad terjadi karena sejak awal kedua belah pihak sudah memiliki kesepakatan unutk melakukan akad murabahah sebagaimana dimaksud.

(5) Objek akad adalah barang-barang yang tidak diharamkan oleh syariah. Hal ini telah ditegaskan oleh pihak bank bahwa obyek jual beli murabahah di Bank Syariah Mandiri KCP Bondowoso adalah objekk akad yang sesuai dengan syariah.

Demikian penjelasan pihak Bank Syariah Mandiri KCP Bondowoso terkait dengan pelaksanaan akad pembiayaan pensiun dengan akad murabahah.

\section{Permasalahan dan Penyelesaiannya}

Menurut pimpinan Bank Syariah Mandiri KCP Bondowoso, sejauh ini belum ada kendala yang berarti dalam pelaksanaan pembiayaan pensiun dengan akad murabahah. Ketika penulis 
menanyakan kendala apa saja yang pernah dihadapi dalam pelaksanaan pembiayaan pensiun dengan akad murabahan tersebut, pihak bank menjawab bahwa secara umum tidak ada kendala terlalu berarti, artinya kalaupun ada, masih bisa diselesaikan dalam tempo relatif singkat. Selama ini menurutnya kendala umum yang biasanya muncul adalah berkaitan dengan proses pelunasan di bank lama jika nasabah sebelumnya memiliki pembiayaan pensiun di bank lain. Untuk mengantisipasinya nasabah biasanya menyediakan sejumlah dana di rekening Bank Syariah Mandiri sampai dengan gaji pensiun masuk ke Bank Syariah Mandiri tempat nasabah melakukan akad pembiayaan pensiun terakhir, yaitu Bank Syariah Mandiri KCP Bondowoso.

Bagaimana penyelesaian yang ditempuh oleh pihak Bank Syariah Mandiri KCP Bondowoso jika terjadi wanprestasi? Menurut penjelasan Dheny Yulianto selaku pimpinan, jika terjadi wanprestasi maka akan dilakukan langkah-langkah penagihan oleh pihak bank dengan cara mengirimkan surat pemberitahuan, surat penagihan, surat peringatan 1 sampai 3 . Namun demikian menurutnya untuk jenis pembiayaan pensiun ini hampir tidak pernah ada wanprestasi karena gaji pensiun nasabah sudah berada di rekening Bank Syariah Mandiri KCP Bondowoso, sehingga angsuran dilakukan secara auto debet pada setiap awal bulan. Dalam hal ini pihak bank tidak menyebutkan langkah selanjutnya seperti langkah musyawarah, penanganan melalui Badan Arbitrase Syariah atau bahkan melalui jalur pengadilan yang mungkin ditempuh apabila surat surat peringatan 1 sampai 3 diabaikan oleh nasabah. Menurut asumsi penulis, hal ini karena belum pernah ada kasus wanprestasi yang terjadi pada produk pembiayaan pensiun tersebut, sehingga langkah-langkah sebagaimana disebutkan oleh pimpinan bank tersebut telah memadai sebagai jalan penyelesaian masalah wanprestasi.

Selanjutnya, apabila nasabah mengalami pailit, apakah bank memberikan waktu hingga nasabah memiliki kesanggupan untuk menyelesaikan hutangnya? Mengenai masalah ini, pihak bank melalui pimpinannya saat ini yaitu Deny Yulianto membenarkan bahwa Bank Syariah Mandiri KCP Bondowoso akan memberikan waktu sampai kapan sanggup menyelesaikan kewajibannya apabila nasalah mengalami pailit dalam usahanya, atau kesulitan lainnya yang menyebabkan nasabah tidak mampu mambayar angsuran atau menyelesaikan utangnya. Kesanggupan ini menurutnya berdasarkan pada hasil kesepakatan pihak bank dengan nasabah pada waktu akah murabahah dilakukan. 


\section{Tinjauan Fatwa DSN-MUI Terhadap Penerapan Akad Murabahah Pada Produk Pembiayaan Pensiun di Bank Syariah Mandiri KCP Bondowoso \\ a. Mekanisme Pembiayaan Pensiun di Bank Syariah Mandiri KCP Bondowoso Menurut Fatwa DSN-MUI}

Fatwa DSN-MUI Nomor 4 Tahun 2000 tentang Akad Murabahah mengatur tentang ketentuan-ketentuan yang harus dipatuhi oleh Lembaga Keuangan Syariah, termasuk Bank Syariah Mandiri dalam melaksanakan pembiayaan berdasarkan akad murabahah. Terkait dengan mekanisme pembiayaan dengan akad murabahah, fatwa tersebut mengatur beberapa ketentuan umum untuk Bank Syariah dan juga untuk nasabah sebagai berikut:

Pertama, ketentuan umum untuk Bank Syariah: ${ }^{9}$

(1) Bank dan nasabah harus melakukan akad murabahah yang bebas (dari unsur) riba. Sebagaimana dijelaskan di atas, bahwa akad yang digunakan dalam pembiayaan pensiun di Bank Syariah Mandiri KCP Bondowoso adalah akad murabahah. Karena itu dapat dipastikan bahwa akad tersebut benar-benar akad yang terbebas dari unsur riba.

(2) Barang yang diperjualbelikan adalah barang yang tidak diharamkan oleh syari'ah Islam. Berdasarkan hasil wawancara penulis dengan pimpinan Bank Syariah Mandiri KCP Bondowoso bahwa akad pembiayaan murabahah adalah akad untuk pembiayaan pembelian kendaraan, tanah, barang dagangan dan lain-lain obyek jual beli yang tentunya sesuai dengan syariah. Dari penjelasan tersebut dapat penulis simpulkan bahwa barang yang diperjualbelikan pada akad tersebut adalah barang yang tidak diharamkan oleh syariah.

(3) Bank membiayai sebagian atau seluruh (jumlah) harga pembelian barang yang telah disepakati kualifikasinya (oleh nasabah dan pihak bank). Bank Syariah Mandiri KCP Bondowoso berdasarkan hasil observasi yang penulis lakukan di lokasi penelitian membiayai seluruh jumlah harga pembelian barang yang telah disepakati kualifikasinya oleh nasabah dan pihak bank.

(4) Bank membeli barang yang diperlukan (atau yang dimohonkan oleh) nasabah atas nama bank sendiri, dan pembelian tersebut harus sah dan bebas (dari unsur) riba. Poin inipun telah dilaksanakan oleh Bank Syariah Mandiri KCP Bondowoso terkait pelaksanaan pembiayaan pensiun dengan akad murabahah tersebut.

\footnotetext{
${ }^{9}$ Fatwa DSN-MUI Nomor 4 Tahun 2000 tentang Akad Murabahah.
} 
(5) Bank harus menyampaikan semua hal yang berkaitan dengan pembelian (secara jelas dan terperinci), misalnya jika pembelian dilakukan dengan cara utang. Hal inipun dibenarkan oleh pihak bank bahwa dalam akad murabahah tersebut dilaksanakan secara jelas jenis barangnya apa, harga jualnya berapa, biaya pengadaan berapa, serta jangka waktu pembiayaan berapa lama termasuk juga jika akan dilunasi sebelum waktunya.

(6) Bank kemudian menjual barang tersebut kepada nasabah (pemohon/pemesan) dengan harga jual senilai harga beli ditambah keuntungan yang diminta. Dalam hal ini Bank harus memberitahukan secara jujur harga pokok barang kepada nasabah beserta biaya yang diperlukan (untuk pengadaannya). Poin ini telah dilaksanakan oleh pihak Bank Syariah Mandiri KCP Bondowoso seperti yang telah dijelaskan.

(7) Nasabah (harus) membayar harga barang yang telah disepakati tersebut dalam jangka waktu tertentu sebagaimana yang telah disepakati bersama. Hal ini telah dilaksanakan oleh nasabah berdasarkan penjelasan pihak Bank Syariah Mandiri KCP Bondowoso.

(8) Untuk mencegah terjadinya penyalahgunaan atau kerusakan akad (murabahah) tersebut, pihak bank dapat mengadakan perjanjian khusus dengan nasabah. Terkait pasal ini, tidak ada pernyataan dari pihak Bank Syariah Mandiri KCP Bondowoso mengenai pelaksanaannya.

(9) Jika pihak bank hendak mewakilkan kepada nasabah untuk membeli barang dari pihak ketiga, akad jual beli murabahah harus dilakukan setelah barang, secara prinsip, dikuasai atau menjadi milik bank. Poin ini telah dilaksanakan oleh Bank Syariah Mandiri KCP Bondowoso berdasarkan penjelasan pihak bank bahwa karena prinsip murabahah adalah jual beli maka benar kepemilikan barang sepenuhnya telah dikuasai bank. Bank juga menjelaskan bahwa dalam beberapa kasus tertentu dalam akad murabahah tersebut akan ditambahkan akad wakalah dimana bank mewakilkan kepada nasabah untuk melakukan pembelian barang sesuai dengan yang diinginkan.

Kedua, ketentuan umum untuk nasabah: ${ }^{10}$

(1) Nasabah mengajukan permohonan dan janji pembelian suatu barang atau aset kepada pihak bank. Poin ini sama persis dengan apa yang telah dijelaskan pihak bank terkait dengan mekanisme pembiayaan pensiun di Bank Syariah Mandiri KCP Bondowoso bahwa calon nasabah datang ke kantor Bank Syariah Mandiri KCP Bondowoso untuk menyerahkan syaratsyarat yang telah ditetapkan dalam pengajuan pembiayaan tersebut.

\footnotetext{
${ }^{10}$ Fatwa DSN-MUI Nomor 4 Tahun 2000 tentang Akad Murabahah.
} 
(2) Jika bank menerima permohonan tersebut, maka bank harus membeli terlebih dahulu aset yang dipesannya secara sah dengan pedagang (yang menjual barang tersebut). Poin inipun sesuai dengan penjelasan pihak bank yang menyatakan bahwa kepemilikan barang sepenuhnya telah dikuasai atau dimiliki oleh bank sebelum diperjualbelikan dengan akad murabahah.

(3) Bank kemudian menawarkan aset tersebut kepada nasabah (yang memesan barang yang dimaksud) dan nasabah harus menerima (membeli)-nya sesuai dengan perjanjian yang telah disepakati bersama, karena secara hukum janji tersebut (bersifat) mengikat, kemudian kedua belah pihak harus membuat kontrak jual beli (dengan akad murabahah). Berdasarkan penelitian yang penulis lakukan, sejauh ini belum pernah ada kasus dimana nasabah menolak pembelian barang yang dipesan di di Bank Syariah Mandiri KCP Bondowoso.

(4) Dalam jual beli (murabahah) ini bank dibolehkan meminta nasabah untuk membayar uang muka saat menandatangani kesepakatan awal pemesanan. Pihak bank berdasarkan data yang penulis peroleh tidak menjelaskan mengenai hal ini, tetapi tidak berarti akad murabahah yang dilaksanakan di Bank Syariah Mandiri KCP Bondowoso tersebut bertentangan dengan poin ini.

(5) Jika nasabah kemudian menolak membeli barang tersebut, maka biaya riil bank harus dibayar dari uang muka (yang telah dibayarkan) tersebut. Sebagaimana yang telah dijelaskan penulis, bahwa di lokasi penelitian belum pernah terjadi kasus seperti pada poin kelima ini.

(6) Jika nilai uang muka kurang dari kerugian yang harus ditanggung oleh bank, bank dapat meminta kembali sisa kerugian tersebut kepada nasabah. Poin inipun belum pernah terjadi di Bank Syariah Mandiri KCP Bondowoso.

(7) Jika nasabah memutuskan untuk membeli barang tersebut, maka ia tinggal membayar sisa harga. Namun jika nasabah memutuskan untuk membatalkan pembelian, maka uang muka menjadi milik bank maksimal sebesar kerugian yang ditanggung oleh bank sebagai akibat dari pembatalan tersebut; dan jika uang muka tidak mencukupi untuk mengganti kerugian bank, maka nasabah wajib melunasi kekurangannya. Poin ini juga belum pernah terjadi di Bank Syariah Mandiri KCP Bondowoso.

Dari penjelasan di atas, dapat penulis katakan bahwa secara umum mekanisme pembiayaan pensiun dengan akad murabahah di Bank Syariah Mandiri KCP Bondowoso terkait dengan ketentuan-ketentuan bagi Bank Syariah dan bagi nasabah telah sesuai dengan fatwa DSN-MUI Nomor 4 Tahun 2000 tentang Akad Murabahah. 


\section{b. Penerapan Akad Murabahah Pada Pembiayaan Pensiun di Bank Syariah Mandiri KCP Bondowoso Menurut Fatwa DSN-MUI}

Fatwa DSN-MUI Nomor 4 Tahun 2000 tentang Akad Murabahah memang tidak mengatur pelaksanaan akad murabahah secara terperinci sebagaimana yang terdapat pada kitab-kitab fiqh. Namun demikian secara substansif dapat dipahami bahwa fatwa tersebut memerintahkan kepada pihak-pihak baik nasabah maupun Bank Syariah untuk melaksanakan transaksi pembiayaan di antaranya berdasarkan aturan dan prinsip jual beli murabahah sebagaimana termaktub dalam fiqh Islam. Karena itu untuk melihat apakah akad murabahah yang dilakukan oleh Bank Syariah Mandiri KCP Bondowoso telah sesuai dengan fatwa DSN-MUI tersebut, perlu dikemukakan mengenai syarat dan rukun, serta prinsip akad dalam fiqh Islam.

Seperti yang telah dijelaskan bahwa rukun-rukun dan syarat-syarat yang mengikat pada rukun yang harus dipenuhi pada akad murabahah adalah:

(1) Sighat. Persetujuan ijab dan qabul harus tercapai berdasarkan kehendak yang bebas atau tanpa paksaan. Apabila pada ijab dan qabul yang dicapai terdapat unsur paksaan maka akad tersebut dianggap fasid atau rusak. Tentang masalah ini ulama Hanafiyah berpendapat bahwa bebas dari paksaan tidak menjadi syarat keabsahan melainkan syarat berlakunya akibat hukum suatu akad. Sehingga menurut pandangan tersebut suatu akad yang dibuat berdasarkan paksaan adalah sah hukumnya, hanya saja akibat hukumnya belum bisa dilaksanakan atau mauquf, yakni menunggu kerelaan pihak yang dipaksa bila akad tersebut telah terjadi. Adapun mengenai pelaksanaan akad murabahah yang dilakukan oleh Bank Syariah Mandiri KCP Bondowoso dapat dikatakan telah sesuai dengan rukun dan syarat pada poin ini, karena dalam akad tersebut telah terpenuhi rukun ijab dan qabul, serta akad dilakukan secara jelas dan tanpa paksaan atau ancaman.

(2) Objek akad. Pada objek akad tidak boleh mengandung unsur gharar (ketidakjelasan), jika hal ini terjadi maka akad yang dilakukan dianggap fasid. Demikian pula dengan syarat objek yang tertentu juga tidak boleh mengandung didapati unsur gharar. Seperti yang telah dijelaskan di muka bahwa barang yang menjadi objek akad pada pembiayaan pensiun dengan akad murabahah di Bank Syariah Mandiri KCP Bondowoso dijelaskan secara terperinci pada waktu akad dilakukan. Penjelasan tersebut terkait dengan jenis barangnya apa, harga jualnya berapa, biaya pengadaan berapa, serta jangka waktu pembiayaan berapa 
lama termasuk juga jika akan dilunasi sebelum waktunya. Adapun barang yang menjadi objek akad adalah barang-barang seperti kendaraan, tanah, barang dagangan dan lain-lain obyek jual beli yang tentunya sesuai dengan syariah. Selain itu barang tersebut telah terlebih dahulu dikuasai dan dimiliki oleh pihan bank sebelum diperjualbelikan dengan akad murabahah. Dari penjelasan tersebut dapat disimpulkan bahwa tidak terdapat unsur gharar (ketidakjelasan) pada objek akad murabahah di Bank Syariah Mandiri KCP Bondowoso.

(3) Sifat akad. Dalam akad tidak boleh mengandung riba (tambahan yang merugikan salah satu pihak) dan maysir (untung-untungan). ${ }^{11}$ Berkaitan dengan pelaksanaan pembiayaan pensiun dengan akad murabahah di Bank Syariah Mandiri KCP Bondowoso, akad tersebut telah sesuai dengan syarat dan rukun pada poin ini secara keseluruhan, karena tidak terdapat unsur-unsur riba dan maysir yang dilarang dalam syariah Islam.

(4) Pelaku akad. Pelaku akad haruslah orang yang memenuhi syarat tamyiz (berakal, baligh) dan memiliki ahliyah (kemampuan melakukan tindakan hukum). Syarat berlakunya akibat hukum ada dua macam yakni: (a) adanya kewenangan sempurna atas objek akad; (b) kewenangan atas tindakan hukum. Kewenangan atas objek akad terpenuhi dengan para pihak mempunyai kepemilikan atas objek bersangkutan atau mendapat kuasa dari pemilik dan pada objek tersebut tidak tersangkut hak orang lain, seperti objek sedang digadaikan atau disewakan. Kewenangan atas tindakan hukum terpenuhi dengan para pihak telah tercapai, tingkat kecakapan bertindak hukum yang dibutuhkan bagi tindakan hukum yang dilakukannya. Ada tindakan hukum yang hanya memerlukan kecakapan bertindak hukum minimal, yaitu mumayiz di mana jika ini terpenuhi, tindakan tersebut sah dan dapat dilaksanakan akibat hukumnya. ${ }^{12}$ Apabila dilihat dari aspek ini, pembiayaan pensiun dengan akad murabahah di Bank Syariah Mandiri KCP Bondowoso telah memenuhi rukun dan syarat ini.

Akad yang telah memenuhi keseluruhan rukun dan syarat keabsahan akad di atas dianggap sebagai akad yang sah. Karena itu dapat ditegaskan bahwa dari sisi pelaksanaan akadnya, pembiayaan pensiun dengan akad murabahah yang dilaksanakan Bank Syariah Mandiri KCP Bondowoso telah sesuai dengan fatwa DSN-MUI Nomor 4 Tahun 2000 Tentang Pembiayaan Murabahah, karena telah terpenuhi rukun-rukun dan syarat-syarat akad dalam fiqh Islam.

\footnotetext{
${ }^{11}$ Ibid, 100.
}

${ }^{12}$ Ibid, 103. 


\section{c. Permasalahan dan Penyelesaian Akad Murabahah Pada Pembiayaan Pensiun di Bank Syariah Mandiri KCP Bondowoso Menurut Fatwa DSN-MUI}

Seperti yang telah dijelaskan, bahwa menurut pengakuan pimpinan Bank Syariah Mandiri KCP Bondowoso, sejauh ini belum ada kendala yang berarti dalam pelaksanaan pembiayaan pensiun dengan akad murabahah. Namun apabila terjadi permasalahan seperti wanprestasi yang dilakukan oleh nasabah, menurut Dheny Yulianto selaku pimpinan, maka akan dilakukan langkah-langkah penagihan oleh pihak bank dengan cara mengirimkan surat pemberitahuan, surat penagihan, surat peringatan 1 sampai 3. Berkaitan dengan hal ini Dheny Yulianto tidak menyebutkan langkah selanjutnya yang mungkin ditempuh apabila surat surat peringatan 1 sampai 3 diabaikan oleh nasabah, seperti langkah musyawarah, penanganan melalui Badan Arbitrase Syariah atau bahkan melalui jalur pengadilan.

Penulis juga sempat menanyakan kepada pimpinan, apabila nasabah mengalami pailit, apakah bank memberikan waktu hingga nasabah memiliki kesanggupan untuk menyelesaikan hutangnya? Deny Yulianto menegaskan bahwa Bank Syariah Mandiri KCP Bondowoso akan memberikan waktu sampai kapan sanggup menyelesaikan kewajibannya apabila nasalah mengalami pailit dalam usahanya. Kesanggupan ini menurutnya berdasarkan pada hasil kesepakatan pihak bank dengan nasabah pada waktu akah murabahah dilakukan.

Penyelesaian masalah seperti ini apabila merujuk kepada fatwa DSN-MUI Nomor 4 Tahun 2000 Tentang Pembiayaan Murabahah, dalam fatwa tersebut ditetapkan bahwa "Jika nasabah telah dinyatakan pailit dan gagal menyelesaikan utangnya, bank harus menunda tagihan utang sampai ia menjadi sanggup kembali, atau berdasarkan kesepakatan." ${ }^{13}$ Berdasarkan pada fatwa tersebut, penulis menyimpulkan bahwa dilihat dari metode penyelesaian masalah yang mungkin terjadi pada pembiayaan pensiun dengan akad murabahah di Bank Syariah Mandiri KCP Bondowoso telah sesuai dengan fatwa DSN-MUI Nomor 4 Tahun 2000 Tentang Pembiayaan Murabahah.

Pada fatwa DSN-MUI Nomor 88 Tahun 2013 bagian kedua poin 1 sub i dinyatakan bahwa "Dalam rangka penyelenggaraan kegiatan investasi dan non investasi, Dana Pensiun Syariah boleh melakukan perjanjian (akad) dengan pihak lain berdasarkan prinsip syariah yang tidak bertentangan dengan peraturan perundang-undangan yang berlaku. Artinya, akad yang dilakukan

\footnotetext{
${ }^{13}$ fatwa DSN-MUI Nomor 4 Tahun 2000 Tentang Pembiayaan Murabahah bagian keenam.
} 
dalam penyelenggaraan pembiayaan pensiun boleh dilakukan dengan akad apapun selama tidak bertentangan dengan peraturan hukum yang berlaku.

Berdasarkan dua poin tersebut dapat disimpulkan bahwa secara keseluruhan implementasi pembiayaan pensiun dengan akad murabahah di Bank Syariah Mandiri KCP Bondowoso telah sesuai dengan fatwa DSN-MUI, baik fatwa DSN-MUI Nomor 4 Tahun 2000 Tentang Pembiayaan Murabahah, maupun fatwa DSN-MUI Nomor 88 Tahun 2013 tentang Pedoman Umum Penyelenggaraan Program Pensiun Berdasarkan Prinsip Syariah tersebut.

\section{KESIMPULAN}

Secara umum mekanisme pembiayaan pensiun dengan akad murabahah di Bank Syariah Mandiri KCP Bondowoso terkait dengan ketentuan-ketentuan bagi Bank Syariah dan bagi nasabah, pelaksanaan akadnya, telah memenuhi rukun dan syarat akad, serta prinsip-prinsip akad yang diterapkan telah sesuai dengan konsep dan teori akad dalam fiqh Islam. Dilihat dari metode penyelesaian masalah yang mungkin terjadi seperti nasabah melakukan wanprestasi atau mengalami pailit, pada pembiayaan pensiun dengan akad murabahah di Bank Syariah Mandiri KCP Bondowoso secara keseluruhan telah sesuai dengan fatwa DSN-MUI, baik fatwa DSNMUI Nomor 4 Tahun 2000 Tentang Pembiayaan Murabahah, maupun fatwa DSN-MUI Nomor 88 Tahun 2013 tentang Pedoman Umum Penyelenggaraan Program Pensiun Berdasarkan Prinsip Syariah. 


\section{DAFTAR PUSTAKA}

Al-Qardhawi, Yusuf. Fatwa: Antara Ketelitian dan Kecerobohan, Jakarta: Gema Insani Press, 1997.

Al-Suyuthi, Jalaluddin. Al-Asybah wa al-Nadha'ir fi qawa 'id wa furu' fiqh al-Syafi'iyah. Beirut: Dar al-Kutub al-Alamiyah, t.th.

Fikri, Ali. Al-Mu'amalah al-Maddiyah wa al-Mu'amalah al-Adabiyah, Mesir: Mustafa alHalabiy, $1358 \mathrm{H}$.

Ghazaly, Abdul Rahman. Fiqh Muamalat, Jakarta : Kencana, 2010.

Hadi, Abd. Memahami Akad-Akad Dalam Perbankan Syariah Serta Dasar Hukumnya, Surabaya: Sinar Terang, 2015.

Hasan, M. Iqbal. Metodologi Penelitian dan Aplikasinya, Bogor: Ghalia Indonesia, 2002.

Khairiyah. Penerapan Akad Murabahah Pada Produk Pembiayaan Pensiun Di Bank Syariah Mandiri KCPP Martapura. Banjarmasin: Fakultas Ekonomi dan Bisnis Islam, Universitas Islam Negeri Antasari Banjarmasin, 2018.

Laina, Zahrotul. Analisis Penyelesaian Pembiayaan Murabahah Bermasalah Di Bmt Insan Sejahtera Cabang Cepiring," Jurusan Muamalah Fakultas Syari'ah Universitas Islam Negeri Walisongo Semarang tahun 2016.

Maryamah, Dwi. Penerapan Akad Murabahah Pada Produk Pembiayaan Pensiun Di Bank Syariah Mandiri KCPP Ngaliyan Semarang. Semarang: Fakultas Ekonomi dan Bisnis Islam Universitas Islam Negeri Walisongo Semarang 2017.

Moleong, Lexi J. Metodologi Penelitian Kualitatif, Bandung: Rosda Karya, 2007.

Nafis, Cholil. Teori Hukum Ekonomi Syariah. Jakarta: UI Press, 2011.

Nazir, Muhammad. Metode Penelitian, Jakarta: Ghalia Indonesia, 1998.

Nisa, Asirotun. Analisis Penerapan Akad Murabahah Terhadap Produk Pembiayaan Pensiunan Pada Bank Syariah Mandiri KCP Wirobrajan. Yogyakarta: Fakultas Hukum Universitas Muhammadiyah Yogyakarta, 2017.

Nujaim, Ibnu. Al-Asybah wa al-Nadha'ir 'ala Mazhabi Abi Hanifah al-Nu'man. Beirut: Dar alKutub al-Alamiyah, t.th..

Qudamah, Syamsuddin Ibn. Al-Syarh al-Kabir, juz 3, Beirut: Dar al-Fikr, tth.

Sabiq, Sayid. Fiqh Sunnah, juz 3, Beirut: Dar al-Fikr, 1981.

Setyaningtyas, Pipit. Implementasi Akad Murabahah Pada Produk Pembiayaan KPR di Bank Syariah Mandiri KCPP Purwokerto. Purwokerto: Fakultas Ekonomi dan Bisnis Islam Institut Agama Islam Negeri (IAIN) Purwokerto, 2016.

Shomad, Abd. Hukum Islam: Penormaan Prinsip Syariah Dalam Hukum Indonesia, Jakarta: Kencana, 2010.

Sugiyono. Metode Penelitian Kualitatif kuantitatif dan R \& D, Bandung: Alfa Beta, 2008.

Sumarsono, Sonny. Metode Riset Sumber Daya Manusia, Yogyakarta: Graha Ilmu, 2004.

Susana, Erni. Pelaksanaan Pembiayaan Dana Talangan Haji Pada Perbankan Syariah. Jurnal Keuangan dan Perbankan, Vol.17, No.2 Mei 2013. 